\title{
Exploring Elementary Teachers', Students' Beliefs and Readiness toward STEAM Education
}

\author{
Dwi Kartini ${ }^{\bowtie 1}$, Ari Widodo² \\ 'Elementary Education Department, Postgraduate School, Universitas Pendidikan Indonesia, Bandung, \\ Indonesia \\ ${ }^{2}$ Faculty of Mathematics and Science Education, Universitas Pendidikan Indonesia, Bandung,
} Indonesia

$\triangle$ dwikartini@upi.edu

\begin{abstract}
STEAM competencies. Most researches on STEAM are mainly focused on students' learning outcomes on STEAM, but only few address non-cognitive aspects. It is necessary to examine elementary teachers and students' beliefs and readiness towards STEAM learning. The purpose of this research is to explore teachers' and students' beliefs and readiness towards STEAM learning. The surveydesigned method was used in this research. A total of 34 elementary school teachers and 36 elementary school students in the city of Bandung participated in this research. The samples were selected using a random sampling technique. Questionnaires were used to collect research data. The results obtained from this research show that students and teachers have positive perceptions in career and benefit of STEAM learning. Students are actually interested in STEAM learning, but the competencies and factors that support and stimulate STEAM learning in schools are still low. The teacher has low competencies to implement STEAM learning. This is due to the lack of knowledge and understanding of teachers about STEAM. This research is expected to contribute to the novelty of teachers' readiness and beliefs in STEAM education in the city of Bandung.
\end{abstract}

Keywords: beliefs, elementary teacher, readiness, STEAM Learning

How to Cite: Kartini, D., \& Widodo, A. (2020). Exploring Elementary Teachers', Students' Beliefs and Readiness toward STEAM Education. Mimbar Sekolah Dasar, 7(1), 54-65. doi: http://dx.doi.org/10.17509/ mimbar-sd.v7il.22453.

INTRODUCTION The fast development of information in the $21^{\text {st }}$ century brings a variety of innovations, especially in the field of learning approaches (Care \& Griffin, 2015; Care, Griffin, \& Wilson, 2018; Griffin, Care, \& McGaw, 2012; Serdyukov, 2017; A.S. Shidiq \& Yamtinah, 2019; Urbani et al., 2017). The presence of technology in learning provides opportunities for both students and teachers to train and adopt a learning framework for acquiring new skills. This learning approach requires collaboration between the teacher and students. Students are required to have the necessary skills as well as creativity. One approach to accommodate the needs of these students is STEAM (Science, Technology, Engineering, Art, and Mathematics) approach (Bush \& Cook, 2019; Cook \& Bush, 2018; Thompson, Barber, \& Bourget, 2018).

The STEAM approach was adopted from the STEM approach which, in recent years, has caught the attention of several researchers in the field of education. STEM is defined as 
Dwi Kartini \& Ari Widodo, Exploring Elementary Teachers', Students' Beliefs and Readiness...

learning to investigate where learning is placed in context and students are asked to solve real problems through the creation of learning innovation opportunities (Watson \& Watson, 2013). STEAM is a learning approach that combines science, technology, engineering, mathematics, and art in the learning process. It aims not only to help to teach science concepts, but also to make students think and work with art and science and inspire them to become creative thinkers across disciplines in learning (Liliawati, Rusnayati, Purwanto, \& Aristantia, 2017)

The presence of STEAM attracts the interest of various parties. Several organizations have sponsored the STEM transition to STEAM by adopting STEM learning by adding "Art and Design" (Yoon \& Baek, 2018). This innovation is considered successful if carried out in accordance with procedures and supported by various parties. The success of STEAM learning is determined by many parties including the government as the policy maker in the curriculum, teachers and also industries (Ge, Ifenthaler, \& Spector, 2015).

Research studies on the application of STEAM have been carried out by many experts, such as the implementation of STEAM to increase student creativity/Christensen \& Knezek, 2015; Engelman et al., 2017; Harris \& de Bruin, 2018; Kennedy, Lee, \& Fontecchio, 2016; Li, Li, Mo, \& Li, 2018), the STEAM approach to improve mastery of concepts (Liliawati et al., 2017), the implementation of STEAM at the secondary school level (Harris \& de Bruin, 2018; Liu, Ludu, \& Holton, 2015; Quigley \& Herro, 2016; Reinhold, Holzberger, \& Seidel, 2018), and the implementation of STEAM at the elementary school level (Jamil, Linder, \& Stegelin, 2018; Lindeman, Jabot, \& Berkley, 2013).

Most of these studies focused on improving the skills possessed by students, the education curriculum and assessment. However, but only few of them pay attention to the teachers' perceptions, attitudes and readiness in teaching (A.S. Shidiq \& Yamtinah, 2019). Teachers' and students' perceptions and readiness also students will influence the way they learn in the classroom (Haney, Lumpe, Czerniak, \& Egan, 2002; Harlen \& Holroyd, 2007).

Moreover, when the STEAM approach is implemented in elementary schools, the Students and the teachers must have good attention towards the STEAM approach, teacher must be ready to teach with STEAM approach, and also the students must be ready to learn with STEAM. Either the teacher or student must be have good perception about STEAM. This research on teacher perceptions is expected to add novelty to research on STEAM and to be one of the references for determining policies on the implementation of STEAM in elementary schools.

Therefore, this research aims to find out the perceptions and readiness of elementary school teachers and students towards the implementation of the STEAM approach at school. BY 
doing this research, it can contribute to the problems and opportunities for applying the STEAM approach in elementary schools.

\section{METHOD}

This study used descriptive method. A survey was conducted on the School Year 2019 - 2020, that involved 34 teachers and 36 students. They came from public and private schools in the city of Bandung. There are 20 Public schools and 5 Private schools. The data on the beliefs and readiness of students and teachers about STEAM were obtained using an instrument in the form of a questionnaire adapted from Saptarani, Widodo, \& Purwianingsih (2019). The research procedure is shown in Figure 1.

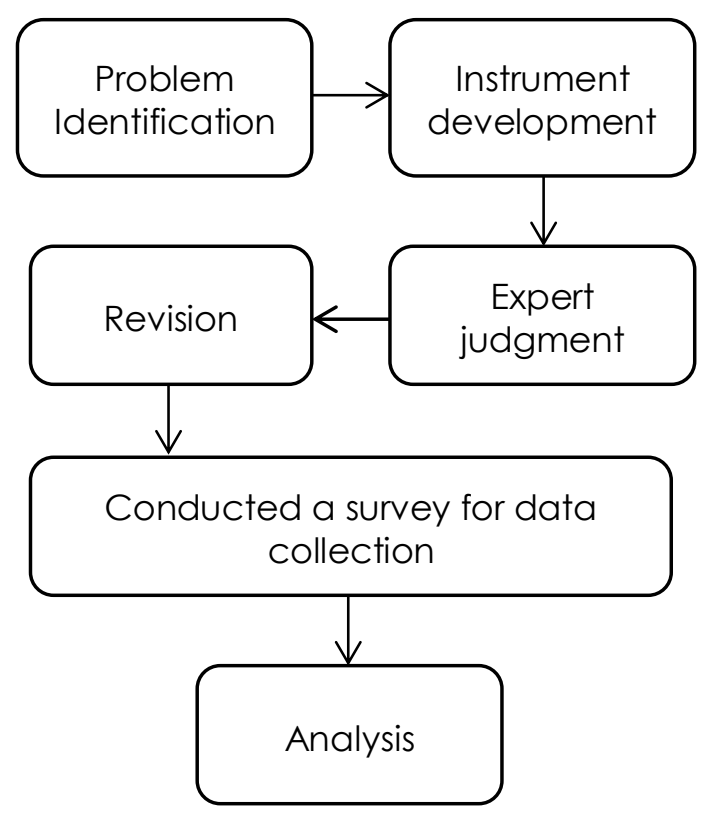

Figure 1. Research Procedure

The question was for teacher and student and was tried on several schools with Google Form. Before this instrument is used, it is first given to an expert to assess whether the developed instrument is feasible to use or not. Items that are not suitable for retrieving the desired data are then revised according to expert advice. Every valid and revised item form the expert is then tried on several schools in Bandung, both public and private schools. A questionnaire was used to explore students' and teachers' perceptions of STEAM.

The teacher questionnaire consisted of three parts; the first part contained demographic profiles, the second part was about facilities and teaching methods, and the last part contained teachers' beliefs and readiness about

Teachers' perceptions of STEAM are categorized based on their views of the importance of STEAM, the influence of significant others, interests in STEAM, STEAM related competencies, and the advantages of STEAM for future careers. Teachers' perceptions are explored through 
Dwi Kartini \& Ari Widodo, Exploring Elementary Teachers', Students' Beliefs and Readiness...

31 questions items that have been categorized in Table 1. The categorizations was adapted from Saptarani, Widodo, \& Purwianingsih (2019).

Table 1. Teacher perception categories of STEAM

\begin{tabular}{llll}
\hline Category & Number of Items & Item Number & $\begin{array}{l}\text { Proportion of the } \\
\text { Entire Item (\%) }\end{array}$ \\
\hline Importance & 8 & $1,9,12,19,20,21,22,23$ & 27 \\
Significant others & 6 & $2,3,4,7,27,31$ & 20 \\
Interest & 5 & $8,10,25,29,30$ & 17 \\
Competency & 7 & $11,13,14,15,16,17,18$ & 4 \\
Career advantage & 5 & $5,6,24,26,28$ & 22 \\
\hline Total & 31 & & 10 \\
\hline
\end{tabular}

The questionnaire administered to students consisted of 48 questions. Whicht the question items is adapted too from Saptarani, Widodo \& Purwaningsih, (2019) . In addition to the five aspects as measured in teacher questionnaire, student questionnaire includes two additional indicators, i.e. readiness to learn STEAM and difficulty in learning STEAM. The questionnaire form consisted of a combination of open-ended questions, closed scale and Likert scale. This questionnaire was adapted from Saptarani, Widodo, \& Purwianingsih, (2019)

The category distribution of each item can be seen in Table 2 with the proportion of each item of all items.

Table 2. Student perception categories of STEAM

\begin{tabular}{cccc}
\hline Category & $\begin{array}{c}\text { Number of } \\
\text { Items }\end{array}$ & Item Number & $\begin{array}{c}\text { Proportion of } \\
\text { the Entire Item } \\
\text { (\%) }\end{array}$ \\
\hline Interest & 10 & $1,5,8,9,23,24,25,26,45,46$ & 21 \\
Difficulty & 4 & $2,4,33,34$ & 8 \\
Competency & 2 & 6,32 & 4 \\
Readiness & 2 & 7,44 & 4 \\
Significant others & 14 & $10,11,13,14,15,27,28,29$, & 29 \\
Career advantage & 7 & $30,31,35,36,37,38$ & 15 \\
Importance & 9 & $3,12,16,17,18,21,22$ & 19 \\
\hline Total & 48 & & 100 \\
\hline
\end{tabular}

\section{RESULTS AND DISCUSSION}

As an innovation in learning, STEAM needs to be further investigated as a first step in determining the curriculum policy going forward. This research provides a basic overview of the readiness in applying the learning. This section describes how the readiness of students and teachers in the application of STEAM learning. 


\section{Teacher Perception of STEAM}

Each item in Table 1 was analyzed and the percentage of each category was obtained, which results in percentages of importance, significant others, interests, competency, and careers advantages according to the teacher. The percentage of each category can be seen in Figure 2.

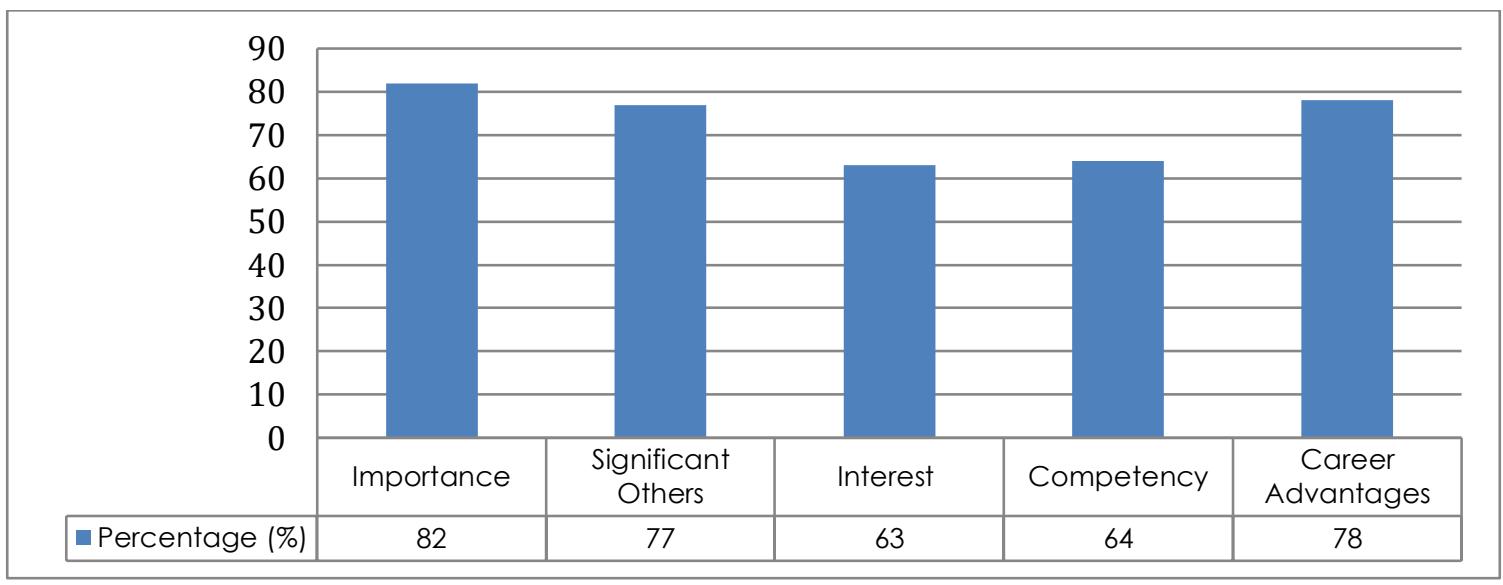

Figure 2. The teacher category percentage about STEAM based on teacher questionnaire Teacher questionnaire shows that STEAM is considered as very important by teachers (average score $82 \%$ ). The significant others indicator is $77 \%$. This shows that there are many other factors that influence students on STEAM learning significantly. Just like students, teachers also have positive perceptions about careers advantages in the STEAM field. This is proven by $78 \%$ of teachers interested in careers in the STEAM field.

Compared to their interest in STEAM learning of only $63 \%$ and competency $64 \%$, of course this is lower than forcing them to teach subjects with STEAM. This result suggests that teachers have low knowledge and understanding of STEAM learning. This indicates that there is a need for training and outreach about STEAM learning for teachers. It is expected that sufficient understanding and knowledge of teachers about STEAM learning their interests and competency will increase.

This research shows that teachers consider STEAM important for them and their students, this is in line with research from Kim \& Bolger (2017) which states that every STEAM discipline provides an important lens for seeing the world and interdisciplinary curriculum design.

the results of the smallest interest and competence in this study indicate that this should be of concern to policy makers. Various studies pay more attention to the interests and competencies of teachers to implement STEAM (Herro \& Quigley, 2017; Herro, Quigley, Herro, \& Quigley, 2016; Herro, Quigley, \& Jacques, 2018; Jho, Hong, \& Song, 2016). In fact, research conducted by So, Ryoo, Park, \& Choi (2019) clearly compared the competencies that were the focus of the researchers to implement STEAM. STEAM teaching competencies can be 
Dwi Kartini \& Ari Widodo, Exploring Elementary Teachers', Students' Beliefs and Readiness...

seen as broadly understood ideas that include teacher's knowledge, skills and attitudes related to designing, creating, and evaluating STEAM teaching and learning activities. Teaching competence is important because it can integrate personal characteristics, knowledge, skills, and attitudes needed for effective performance in various teaching contexts (So et al., 2019)

The research result of Reinhold et al (2018) shows that school is the most important factor in student career orientation, so the learning patterns in it have high influence. In addition, the research of Blotnicky, Franz-odendaal, French, \& Joy (2018) shows that STEAM learning can increase their interest in pursuing careers involving science, technology, engineering, and mathematics.

\section{Student Perception of STEAM}

Each item in Table 2 is analyzed, which results in the percentage of interest, difficulty, competency, readiness, significant others, importance of students. The percentage of each category can be seen in Figure 2.

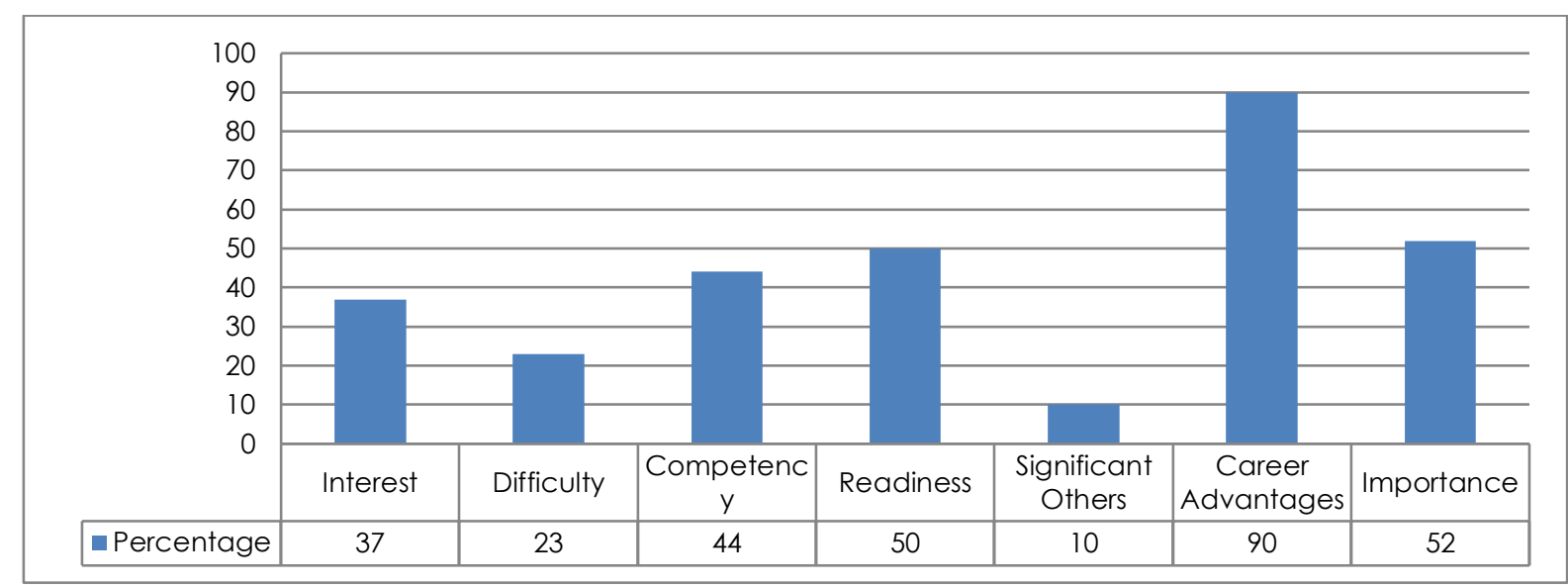

Figure 2. Results of student's questionnaire

Further detailed analyses of students' responses to the questionnaire shows that students are less interested in reading books on science, art, mathematics, technology, and engineering. The relationship of students with learning is directly related to subjects taught using STEAM. The percentage scores in this section indicate low students' interests in subjects related to STEAM. This contrasts with previous researches, where senior high school students were more interested in STEM learning because science classes were very popular among them (Saptarani et al., 2019). This shows the lack of socialization of science learning and art in their circles. There are more questions about the aspects of interests which include watching documentaries and the desire to visit science exhibitions at around $19.4 \%$. This means they will be more interested if given a good stimulus about subjects related to STEAM. 
In the second aspect, $23 \%$ of students describe difficulties in subjects related to STEAM learning. In general, the application of STEAM in elementary student learning can encourage them to design, develop, and utilize technology. However, because it is also still less popular among students, they consider it difficult to implement. The results obtained are different from Kim \& Kim (2016), which found that students can develop a complete understanding of scientific principles and creativity by utilizing emotions through the exploration of the beauty of traditional culture. Things that are close to students' daily lives, such as culture, can make it easier for them to adapt to STEAM learning. The percentage of questions about subject difficulties related to STEAM learning is $8.3 \%$.

The percentage of the third aspect, which is the competency of students in subjects taught with the application of STEAM, is $44 \%$. This figure is higher than the two previous aspects. This illustrates that students are ready for STEAM learning that is carried out in schools. The results obtained in the third aspect are followed by a high percentage in the fourth aspect, students' readiness in learning STEAM, by 50\%. The research conducted by Bush \& Cook (2019) shows that STEAM learning provides a means of transdisciplinary learning experiences, so students are always ready and investing in problem solving as they strive to make the world a better place.

The fifth aspect is significant others to support STEAM learning. Based on questionnaire results, the significant others indicator has the lowest value of $10 \%$. This means that the low supporting factors of STEAM learning in schools. The significant others has a very small contribution compared to the interests, readiness, difficulties and competencies of the students in subjects related to STEAM. The research of Li et al (2018) shows that STEAM Learning gradually becomes a new learning framework that does not have specific goals with subjects. However, this learning is designed to address the lack of curriculum, teachers and teaching materials that are not innovative. In general, the exposures of the research results are both internal and external influences because STEAM answers all the needs in the education sector today.

The sixth aspect is career orientation. The percentage of this aspect is $90 \%$, a very high score compared to the five previous aspects. This shows that students are attracted to their careers related to subjects related to STEAM. This means that their hopes for their careers will be better in the fields of science and art related to income. Students believe careers in the STEAM field get a better income. But competency for STEAM is still low. This can be seen from the small data of the cloudy Significant others of STEAM learning in schools. So students face unpreparedness in STEAM learning. To overcome this, teacher must make a strategy to make students ready and have no difficulty in STEAM learning 
Dwi Kartini \& Ari Widodo, Exploring Elementary Teachers', Students' Beliefs and Readiness...

This result is in line with students' perceptions about the importance of STEAM, as many as $52 \%$ of students consider STEAM to be importance. The research result of Shin, Rachmatullah, \& Roshayanti (2018) shows that educating a qualified STEAM workforce requires consideration and development of the individual career. ThUs, STEAM career is one important indicator of the student career development. Career motivation has a different pattern in each country. Students' motivations towards STEAM are influenced by a combination of countries, levels of education, and gender in complex ways. This result highlights the need to consider the sociocultural context inherent in each country related to the gender and education level when examining the STEAM career motivation of students.

Overall, the average percentage of all student questionnaires is $76.5 \%$. This shows that students are positive perception in learning subjects related to STEAM. Students are actually interested in STEAM learning, but the competencies and factors that support and stimulate STEAM learning in schools are still low.

STEAM as a learning approach does not have specific objectives in each subject. However, in providing learning experiences in accordance with the STEAM approach, it is important to build the skills, attitudes and knowledge that students will show after they have completed an education program or graduated later (Erwin, 2017). In the next section, the teacher's perceptions of the application of STEAM learning will be elaborated.

\section{CONCLUSION}

This study finds that teacher and students have positive perceptions of STEAM. This is evident from their attitudes that showing positive opinions about career advantages in STEAM. These results prove that students 'and teachers' perceptions of STEAM are important.

This study also found that teachers were ready to implement STEAM in elementary schools. However, some teachers still have problems with their skills and knowledge about STEAM. Therefore this study recommends training for elementary school teachers to implement the STEAM approach. The problems and possibilities presented in this study are expected to contribute as a reference for teachers and policy makers to implement STEAM in primary schools.Teachers' perceptions, interests and competencies to implement STEAM learning, greatly affect students' interests and perceptions about STEAM. Teachers, who have good knowledge and understanding of STEAM, will more likely promote students to have good perceptions about STEAM.

\section{ACKNOWLEDGMENT}

We would like to thank the teachers and students who participated in this research.

\section{REFERENCES}

Blotnicky, K. A., Franz-odendaal, T., French, F., \& Joy, P. (2018). A study of the correlation 
between STEM career knowledge, mathematics self- efficacy, career interests, and career activities on the likelihood of pursuing a STEM career among middle school students. International Journal of STEM Education, 5(22), 1-15.

Bush, S. B., \& Cook, K. L. (2019). Structuring STEAM Inquiries: Lessons Learned from Practice. In M. S. Khine \& S. Areepattamannil (Eds.), STEAM Education: Theory and Practice (pp. 1920). Cham: Springer.

Care, E., \& Griffin, P. (2015). Assessment and Teaching of 21 st Century Skills. (P. Griffin \& E. Care, Eds.). Dordrecht: Springer Netherlands. https://doi.org/10.1007/978-94-017-9395-7

Care, E., Griffin, P., \& Wilson, M. (2018). Assessment and Teaching of 21 st Century Skills. (E. Care, P. Griffin, \& M. Wilson, Eds.). Cham: Springer International Publishing. https://doi.org/10.1007/978-3-319-65368-6

Christensen, R., \& Knezek, G. (2015). Emerging Technologies for STEAM Education. Emerging Technologies for STEAM Education. https://doi.org/10.1007/978-3-319-02573-5

Cook, K. L., \& Bush, S. B. (2018). Design thinking in integrated STEAM learning: Surveying the landscape and exploring exemplars in elementary grades. School Science AndMathematics, (January), 1-11. https://doi.org/10.1111/ssm.12268

Engelman, S., Magerko, B., McKlin, T., Miller, M., Edwards, D., \& Freeman, J. (2017). Creativity in authentic STEAM education with Earsketch. In Proceedings of the Conference on Integrating Technology into Computer Science Education, ITiCSE (pp. 183-188). https://doi.org/10.1145/3017680.3017763

Erwin, H. E. (2017). Full STEAM Ahead in Physical Education. Journal of Physical Education, Recreation \& Dance, 88(1), 3-4. https://doi.org/10.1080/07303084.2016.1249759

Ge, X., Ifenthaler, D., \& Spector, J. M. (2015). Moving Forward with STEAM Education. Educational Comuunications and Technologies, 383-395. https://doi.org/10.1007/978-3319-02573-5

Griffin, P., Care, E., \& McGaw, B. (2012). Assessment and Teaching of 21st Century Skills. (P. Griffin, B. McGaw, \& E. Care, Eds.). Dordrecht: Springer Netherlands. https://doi.org/10.1007/978-94-007-2324-5

Haney, J. J., Lumpe, A. T., Czerniak, C. M., \& Egan, V. (2002). From Beliefs to Actions: The Beliefs and Actions of Teachers Implementing Change. Journal of Science Teacher Education, 13(3), 171-187.

Harlen, W., \& Holroyd, C. (2007). Primary teachers ' understanding of concepts of science: 
Dwi Kartini \& Ari Widodo, Exploring Elementary Teachers', Students' Beliefs and Readiness...

impact on confidence and teaching. International Journal of Science Education, 19(1), 93-105. https://doi.org/10.1080/0950069970190107

Harris, A., \& de Bruin, L. R. (2018). Secondary school creativity, teacher practice and STEAM education: An international study. Journal of Educational Change, 19(2), 153-179. https://doi.org/10.1007/s10833-017-9311-2

Herro, D., \& Quigley, C. (2017). Exploring teachers' perceptions of STEAM teaching through professional development: implications for teacher educators. Professional Development in Education, 43(3), 416-438. https://doi.org/10.1080/19415257.2016.1205507

Herro, D., Quigley, C., Herro, D., \& Quigley, C. (2016). Innovating with STEAM in middle school classrooms: remixing education. On the Horizon. https://doi.org/10.1108/OTH-03-20160008

Herro, D., Quigley, C., \& Jacques, L. A. (2018). Examining technology integration in middle school STEAM units. Technology, Pedagogy and Education, 27(4), 485-498. https://doi.org/10.1080/1475939X.2018.1514322

Jamil, F. M., Linder, S. M., \& Stegelin, D. A. (2018). Early Childhood Teacher Beliefs About STEAM Education After a Professional Development Conference. Early Childhood Education Journal, 46(4), 409-417. https://doi.org/10.1007/s10643-017-0875-5

Jho, H., Hong, O., \& Song, J. (2016). An analysis of STEM/STEAM teacher education in Korea with a case study of two schools from a community of practice perspective. Eurasia Journal of Mathematics, Science and Technology Education, 12(7), 1843-1862. https://doi.org/10.12973/eurasia.2016.1538a

Kennedy, J., Lee, E., \& Fontecchio, A. (2016). STEAM approach by integrating the arts and STEM through origami in K-12. In Proceedings - Frontiers in Education Conference, FIE (Vol. 2016-Novem, pp. 2-6). https://doi.org/10.1109/FIE.2016.7757415

Kim, B. H., \& Kim, J. (2016). Development and validation of evaluation indicators for teaching competency in STEAM education in Korea. Eurasia Journal of Mathematics, Science and Technology Education, 12(7), 1909-1924. https://doi.org/10.12973/eurasia.2016.1537a

Li, W., Li, G., Mo, W., \& Li, J. (2018). The Influence of STEAM Education on the Improvment of Studentsr Creative Thinking. In Advances in Social Science, Education and Humanities Research, (Vol. 232, pp. 924-927). https://doi.org/10.2991/icadce-18.2018.200

Liliawati, W., Rusnayati, H., Purwanto, \& Aristantia, G. (2017). Implementation of STEAM 
Education to Improve Mastery Concept. IOP Conf. Series: Materials Science and Engineering, 288(012148). https://doi.org/10.1088/1757-899X/288/1/012148

Lindeman, K. W., Jabot, M., \& Berkley, M. T. (2013). Learning Across the Early Childhood Curriculum. In Advances in Early Education and Day Care (Vol. 17, p. iii). https://doi.org/10.1108/s0270-4021 (2013)0000017018

Liu, H., Ludu, M., \& Holton, D. (2015). Can K-12 Math Teachers Train Students to Make Valid Logical Reasoning? A Question Affecting 21st Century Skills. In Emerging Technologies for STEAM Education, (pp. 331-353). https://doi.org/10.1007/978-3-319-02573-5

Quigley, C. F., \& Herro, D. (2016). "“ Finding the Joy in the Unknown "': Implementation of STEAM Teaching Practices in Middle School Science and Math Classrooms. Journal of Science Education and Technology. https://doi.org/10.1007/s10956-016-9602-z

Reinhold, S., Holzberger, D., \& Seidel, T. (2018). Encouraging a career in science : a research review of secondary schools ' effects on students ' STEM orientation secondary schools ' effects on students' STEM orientation. Studies in Science Education, 7267, 1-35. https://doi.org/10.1080/03057267.2018.1442900

Saptarani, D., Widodo, A., \& Purwianingsih, W. (2019). Biology teachers and high school students perceptions about STEM learning. Journal of Physics: Conference Series, 1157(4), 0-6. https://doi.org/10.1088/1742-6596/1157/4/042007

Serdyukov, P. (2017). Innovation in education: what works, what doesn ' $\dagger$, and what to do about it? Journal of Research in Innovative Teaching \& Learning, 10(1), 4-33. https://doi.org/10.1 108/JRIT-10-2016-0007

Shidiq, A.S., \& Yamtinah, S. (2019). Pre-service chemistry teachers' attitudes and attributes toward the twenty-first century skills. In Journal of Physics: Conference Series (Vol. 1157). https://doi.org/10.1088/1742-6596/1157/4/042014

Shidiq, Ari Syahidul, \& Yamtinah, S. (2019). Pre-service chemistry teachers ' attitudes and attributes toward the twenty-first century skills. Journal of Physics: Conference Series, 1157(042014), 1-8. https://doi.org/10.1088/1742-6596/1157/4/042014

Shin, S., Rachmatullah, A., \& Roshayanti, F. (2018). Career motivation of secondary students in STEM: a cross-cultural study between Korea and Indonesia. International Journal for Educational and Vocational Guidance, 18(2), 203-231. https://doi.org/10.1007/s10775$\underline{017-9355-0}$

So, H. J., Ryoo, D., Park, H., \& Choi, H. (2019). What Constitutes Korean Pre-service Teachers' 
Dwi Kartini \& Ari Widodo, Exploring Elementary Teachers', Students' Beliefs and Readiness...

Competency in STEAM Education: Examining the Multi-functional Structure. Asia-Pacific Education Researcher, 28(1), 47-61. https://doi.org/10.1007/s40299-018-0410-5

Thompson, C. J., Barber, K., \& Bourget, E. M. (2018). Steam (Science, Technology, Engineering, Art, And Mathematics) Education And Teachers' Pedagogical Discontentment Levels. PEOPLE: International Journal of Social Sciences, 4(3), 496-518. https://doi.org/10.20319/pijss.2018.43.496518

Ucar, S. (2012). How Do Pre-Service Science Teachers ' Views on Science, Scientists, and Science Teaching Change Over Time in a Science Teacher Training Program? Journal of Science Education and Technology, 21, 255-266. https://doi.org/10.1007/s10956-011$9311-6$

Urbani, J. J. M., Truesdell, E., Urbani, J. J. M., Roshandel, S., Michaels, R., Truesdell, E., ... Truesdell, E. (2017). Assessment and Teaching of 21st Century Skills. Educacion Quimica, 1(1), 1709-1716. https://doi.org/10.1016/j.sbspro.2009.01.303

Watson, A. D., \& Watson, G. H. (2013). Transitioning STEM to STEAM: Reformation of Engineering Education. The Journal For Quality \& Participation, 1-4.

Yoon, M. B., \& Baek, J. E. (2018). Development and application of the STEAM education program based on the soccer robot for elementary students. International Journal of Mobile and Blended Learning, 10(3), 11-22. https://doi.org/10.4018/IJMBL.2018070102 